\title{
The Growth of Protonema Cells and Rhizoids in Bracken
}

\author{
Chihiro Takahashi \\ Biological Laboratory, Department of General Education, \\ Nagoya University, Mizuho-ku, Nagoya, Japan
}

Received July 11, 1960

It has been known that there are various types of plant cell growth (Frey-Wyssling 1959). One of them is the tip growth in which the cell elongation occurs only in the cell tip. Hyphae, root hairs, pollen tubes, flax and other fibers and fern protonemata are examples of cells which show the tip growth. In order to confirm the tip growth previous investigators only observed the tip form of cells or indefinite "marks", that is, some cell form change that might occur. But using a micromanipulator the author made definite marks at will anywhere on the wall surface of the given parts. This paper presents the results obtained by the observation on the tip growth of each cell constituting protonema (protonema cell) and of rhizoids in bracken with special reference to the distribution of their elongating ability. The study was carried out in July and August, 1957.

Protonemata of bracken, Pteridium aquilinum (L.) Kuhn var. latiusculum (Desv.) Und., obtained from cultures were used in this study. Spores were sown on the culture medium ( $1 / 5$ dilute Knop's solution solidified with 1.5 per cent agar). Cultures were kept under the diffused light and at the room temperature in the laboratory. A definite while after marking with the micromanipulator, the author measured the shift of these marks resulting from the growth of the given parts of the cell wall under the microscope $(\times 400)$. For the mark sudan III excessively dissolved in lanolin or finely-ground charcoal powder was used. But the author recommends the mark with the latter because of the following reasons: 1) Dotted marks with the former on the well-grown part frequently spread out obscurely, so that the exact measurement is impossible. 2) Lanolin is so sticky that marking is apt to injure the

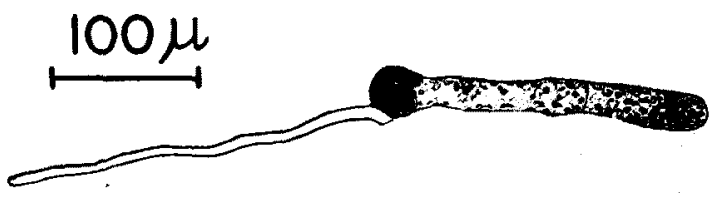

Fig. 1. Bracken protonema in its early stage, consisting of two protonema cells and a rhizoid. normal growth of the cell, especially of the fine rhizoid.

The gametophyte of bracken, as well as that of many other ferns, assumes a protonema in its early stage of development which consists of several cells linearly arranged (Fig. 1). The protonema is formed as a result of the successive one dimensional cell divisions, except for the case of 
rhizoid formation, and it grows phototropically orientated. How many cells make up a protonema depends on the culture condition. But unless the condition is extremely unfavourable, the apical portion of the protonema develops sooner or later into a young prothallium organized two-dimensionally. Except for the rhizoid formation, the cell multiplication of protonema occurs exclusively in the apical cell. The elongation of protonema as a whole is attributed mainly to that of the apical cell as shown in Fig. 2 and is mentioned later.

In order to study the elongation of the apical cell, the author made about 300 marks on 76 apical cells and measured their shift after a day or two. The results meas. ured 2 days after marking are shown in Fig. 3A. It has been revealed that the apical cell displays a typical tip growth. The elongating ability of the very tip of the apical cell is the largest, and its mean value of elongation

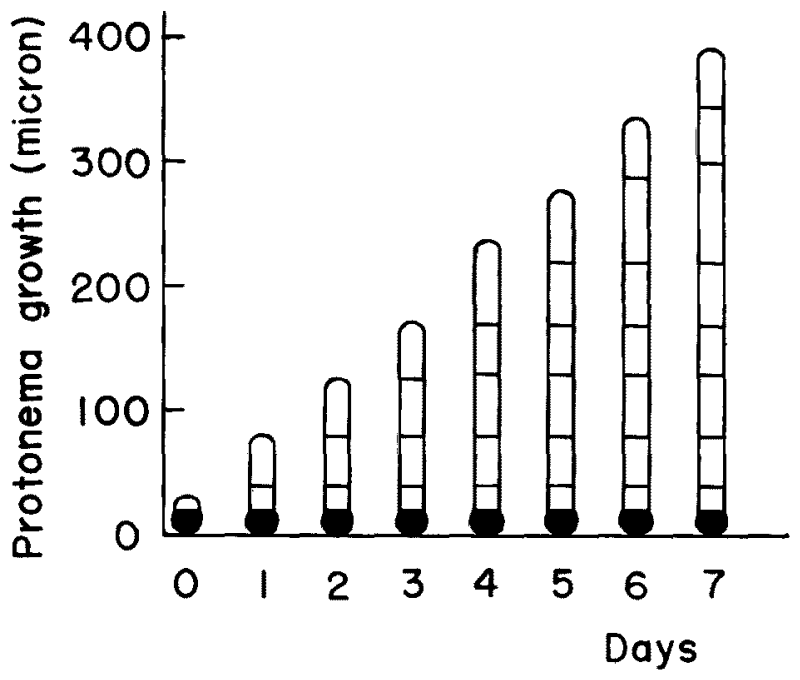

Fig. 2. An example of growth of bracken protonema. Exine in black. reaches nearly 45 microns per day. On the contrary, the farther from the apical tip the given part is, the less the ability of elongation is. The region over 10 microns far from the apical tip elongates very slightly, and the region more than 30 microns far does not elongate at all. Also, 10 of 42 subapical cells and 2 of 30 third cells (the next cell of the subapical cell) were observed to elongate and make the "tip growth" in the same manner as the apical cell. Some of them are shown in Fig. 3B and C. Their elongation is not so large as that of the apical cell and not all of them elongate, contrary to the case of the apical cell. The possibility and ability of the growth of protonema cells decrease in the following order: The apical cell, the subapical cell and the third cell. The fourth cell shows no elongation. It was, therefore, concluded that not only each protonema cell but also the protonema as a whole makes the tip growth.

The rhizoid of this fern has a maximum length of 800 microns and is 30 and 9 microns in diameter, respectively, at the proximal and distal parts. The maximal velocity of its growth is 12.5 microns per hour. 104 marks were made on 25 rhizoids including both very young, short ones and pretty grown ones, and their shift was measured after a day. In the case of rhizoids even the mark made on the very tip in appearance did not shift. From 
this fact it is evident that the elongation ability of rhizoids is limited only to the part within 1 micron or less from the tip of the calotte-like apical end.

The cell elongating only at its tip usually has free end, though in the case of cotton hairs the entire wall is involved in elongation as revealed by
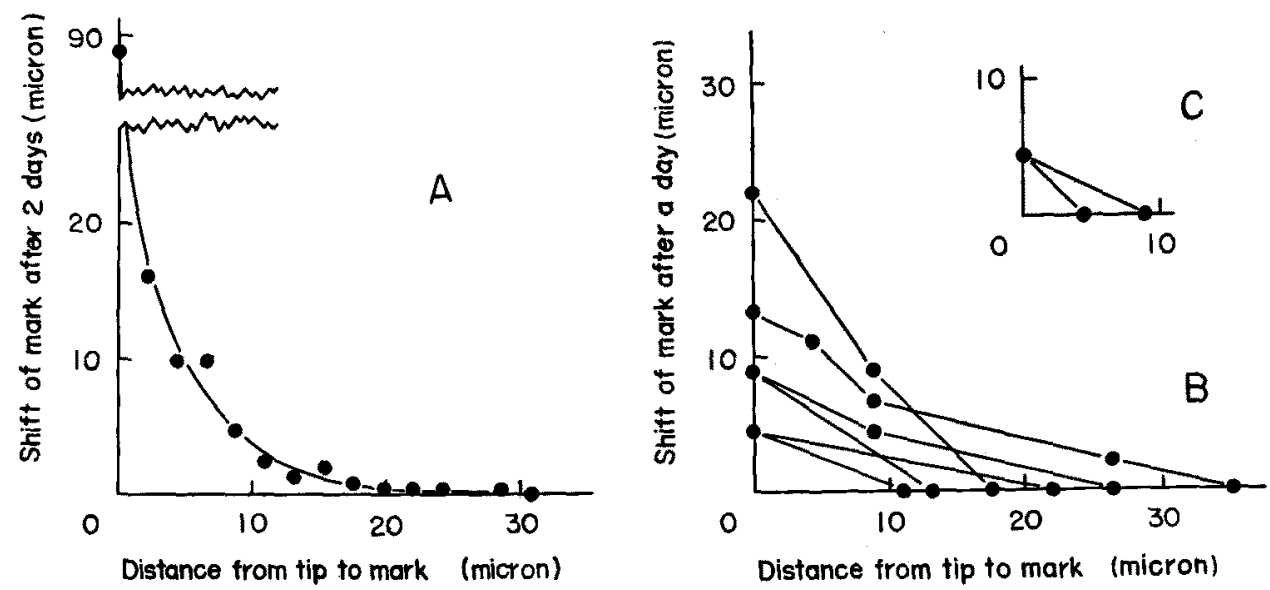

Fig. 3. The distribution of elongating ability in the apical cell (A), the subapical cell (B and the third cell $(\mathrm{C})$ of bracken protonema.

the radioautography (O'Kelley 1953). The occurrence of the tip growth previously reported was indirectly concluded from the morphological observation of the tip form excepting the case of root hairs.

Reinhardt (1892) pointed out the tip growth in Peziza hypha from the observation of bending, branching and form-changing of the hyphal tip. The growing portion of Basidiobolus hypha is within 15 to 20 microns of its tip (Raciborski 1907). The tip growth of root hairs was shown by Reinhardt (1892) and Haberlandt (1918), who used minium powder and rice starch grains, respectively, for the mark. From the measurement of morphological marks resulting from bending and diameter change of tubes, Schoch-Bodmer (1945) came to the conclusion that pollen tubes exhibit the tip growth. The growing portion was within 4 to 7 microns of the tube tip. She also reported the occurrence of the tip growth in Linum and Sparmannia fibers from the observation of the tip form such as branching (Schoch-Bodmer and Huber 1945, 1946). The tip growth of pollen tubes was reported by Iwanami (1952) who observed the growth of moniliform pollen tubes on the medium containing 2,4-D. The tip growth of pollen tubes was evidently proved by the present author using the same method as in the present study (unpublished). As revealed by the electron micrographic study, the tip of pollen tubes and root hairs has a cellulose structure different from other parts of the cell (O'Kelley and Carr 1954). Mohr (1956) cultured the abnormally lanky protonema of Dryopteris under the low intensity of light and confirmed that the growing zone of the apical cell is restricted within 20 microns of its 
tip, when the cell bends phototropically. In the present study materials growing normally were used. Using the micromanipulator the author revealed the distribution of elongating ability, not only qualitatively but also quantitatively. The data obtained are the most accurate and detailed of those reported so far. In Pteris protonema Sugai obtained the same result as the present author (personal communication).

Bünning (1953) said "Ohne Polarität keine Differenzierung". It has been known that in a Dryopteris protonema or in a protonema cell there is the apico-basal polarity which appears under various physiological gradients, such as the osmotic value, permeability, behaviour to dyes (Reuter 1953) and susceptibility to colchicine (Nakazawa 1959). The present work also evidently gives the fact that there exists the apico-basal polarity of the possibility and ability of elongation, not only in each protonema cell but also in a protonema as a whole.

Rhizoids are very fine and slender, and their growing portion is localized within 1 micron or less of their tip, so that instruments and methods used in the present experiments did not give the results as satisfactorily as in the case of protonema. In the case of root hairs in Avena, the circumstance was the same (unpublished). But the distribution of their elongating ability is supposed to be the same as that in protonema cells shown in Fig. 3.

The author's thanks are due to Profs. M. Kumazawa, T. Shimamura and I. Harada for their guidance and encouragement.

\section{Summary}

The elongation of protonema cells and rhizoids of bracken was studied by the direct measurement of shift of marks which were made on wall surface with the micromanipulator. Those cells showed a typical tip growth. The apical cell of protonema elongates chiefly in its apical dome, very slightly in the region more than 10 microns from the apical end, and not at all in the region over 30 microns from the apical end. Some of the subapical cells elongate and make the tip growth, but their elongation is less than that of the apical cell. The third cell, less often than the subapical cell, grows slightly at its apical end. The fourth cell does not elongate. There exists the polarity, from apex to base, of the possibility and ability of elongation not only in each protonema cell but also in a protonema as a whole. The nearer to the apex the given part is, the larger the possibility and ability of elongation are, and vice versa. Rhizoids elongate at the part within 1 micron or less of their tip.

\section{References}

Bünning, E. 1953. Entwicklungs- und Bewegungsphysiologie der Pflanze. Berlin。 Frey-Wyssling, A. 1959. Die pflanzliche Zellwand. Berlin.

Haberlandt, G. 1918. Physiologische Pflanzenanatomie. Leipzig. 
Iwanami, Y. 1952. The physiological researches of the pollen (III). Bot. Mag. Tokyo 65: 199.

Mohr, H. 1956. Die Abhängigkeit des Protonemawachstums und der Protonemapolalität bei Farnen von Licht. Planta 47: 127-158.

Nakazawa, S. 1959. Morphogenesis of the fern protonema. I. Polar susceptibility to colchicine in Dryopteris varia. Phyton (Argentina) 12: 59-64.

O'Kelley, J. C. 1953 . The use of $\mathrm{C}^{14}$ in locating growth regions in the cell walls of elongating cotton fibers. Plant Physiol. 28: 281-286.

- and Carr, P. H. 1954. An electron micrographic study of the cell walls of elongating cotton fibers, root hairs and pollen tubes, Amer. J. Bot. 41: 261-264.

Raciborski, M. M. 1907. Uber Schrittwachstum der Zelle. Bull. Intern. Acad. Sci. Cracovie Cl. Math. Nat. 898-936.

Reinhardt, M. O. 1892. Das Wachstum der Pilzhyphen. Jahrb. wiss. Bot. 23: 479-566.

Reuter, L. 1953. A contribution to the cellphysiologic analysis of growth and morphogenesis in fern prothallia. Protoplasma B 42: 1-29.

Schoch-Bodmer, H. 1945. Utber das Spizenwachstum der Pollenschläuche. Ber. schweiz. bot. Ges. 55: 154-168.

- and Huber, P. 1945. Das Spitzenwachstum der Fasern bei Linum perrenne L. Experientia 1: $327-328$.

- and - 1946. Wachstumstypen plastischer Pflanzenmembranen. Mitt. naturforsch. Ges. Schaffhausen 21: 29-43. 